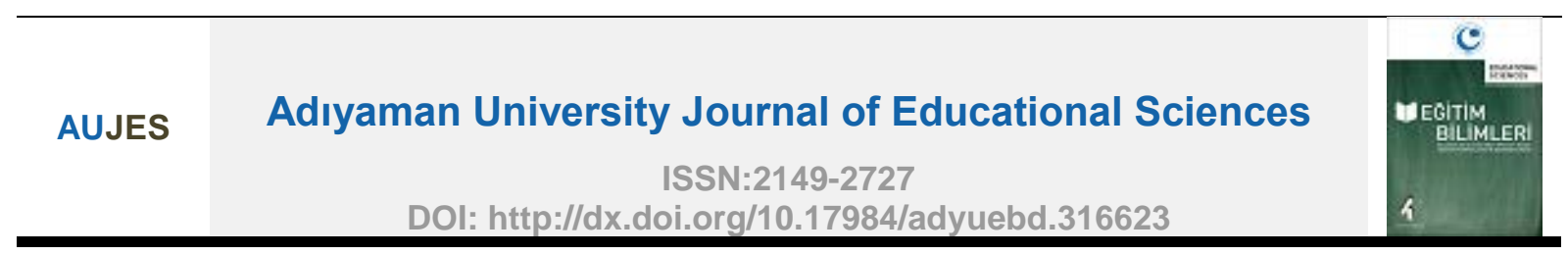

\title{
Teaching Ninth Grade "Biological Diversity and Protection" Topic Using Stations Technique and Satisfaction of the Students from the Implementation
}

\author{
Duygu KARA EKEMEN, Ali Derya ATIKK ${ }^{2 *}$, Figen ERKOÇ
}

${ }^{1}$ MEB, Şereflikoçhisar Tuz Gölü Anatolian High School, Turkey

${ }^{2}$ MEB, Genç Osman Anatolian High School, Turkey

${ }^{3}$ Gazi University, Faculty of Education, Department of Biology Education, Turkey

\begin{tabular}{l} 
ARTICLE INFO \\
\hline Article History: \\
Received \\
29.05 .2017 \\
Received in revised \\
form 19.10.2017 \\
Accepted \\
20.10.2017 \\
Available online \\
28.12.2017
\end{tabular}

\section{ABSTRACT}

Replacement of instruction-based and passive student methods and techniques with new educational approach facilitating students active participation is important to ensure effective, long-lasting learning. Stations technique contends work where students are active in the learning and teaching process and participate by exploring and effectively involve in the process. This study was carried out during the 2015/2016 spring term academic year in Şereflikoçhisar province of Ankara, in Tuz Gölü Anatolian High School, 9th grade students $(\mathrm{N}=31)$. Teaching "Biological Diversity and its Protection" topic in the 9th grade curriculum was delivered using stations technique during six instruction hours. Biological diversity topic was chosen since it is taught during the last period of the semester and it is very important. The objective of this study is to determine students' level of satisfaction and pleasure from the stations techniques used to teach biological diversity topics. To this aim, Stations Technique Satisfaction Instrument (IMTÖ) was developed by researchers and applied. Our results showed that the students were satisfied with the stations technique, enjoyed working at the stations, felt comfortable; however it was somewhat tiring. The stations technique provided active participation of the students to the process, improved their motivation and encouraged group work, therefore it can be applied to other topics and courses.

(C) 2017 AUJES. All rights reserved

Keywords: Station technique, learning stations, biodiversity, secondary education

\section{Extended Abstract}

\section{Purpose}

One of the new educational approaches is to have the student in an active role; stations technique is one of these methodologies. The teacher is only guiding and therefore with a student-centered material delivery, students attitudes and achievement are expected to be affected positively. Biological diversity and protection are the subjects of diverse fields and a multidisciplinary curriculum content is necessary to facilitate learning at all school levels. The

\footnotetext{
*Corressponding author's address: MEB, Genç Osman Anatolian High School, Ankara e-mail: drada0505@gmail.com
} 
overall goal of the present study was to investigate students' level of satisfaction and pleasure from the stations technique used to teach biological diversity topics. Biology course is perceived as a difficult subject to teach, here we use biological diversity as a model topic to teach using stations technique, and measure student satisfaction using an instrument developed by the researchers.

The main research questions of this study were as follows:

(1) What is the level of satisfaction of the students' to stations technique?

(2) What are strengths of the technique based on students' views?

(3) What are the weaknesses of the technique based on students' views?

(4) What are the distresses experienced during delivery of the stations technique?

\section{Method}

Research model: The research is a survey model of quantitative research, designed as descriptive field and survey investigation. The study group was a sample of 31 students attending $9^{\text {th }}$ grade in Tuz Gölü Anatolian High School in Şereflikoçhisar province of Ankara, Turkey. Study was carried out during 2015/2016 academic year. The pilot work (instrument development stage) sample consisted of a total of 199 students attending $10^{\text {th }}, 11^{\text {th }}$ and $12^{\text {th }}$ grades of Şereflikoçhisar schools, and were 102 girls, 97 boys. The study group (implementation stage) were 31 students (17 girls, 14 boys) in class 9/A of Tuz Gölü Anatolian High School. Data collection and respondents: The data collection tool was developed by the researchers ITMÖ instrument. The students were given instructions to complete the questionnaire, after four weeks of various activities on "Biological Diversity and Protection" were applied with stations technique; and ITMÖ was tested at the end of the period. Implementation: Timing, activity contents, number of stations were planned pursuant to the 2015/2016 academic year high school curriculum. Classroom was prepared for the implementation with material (worksheets, answer keys, videos, puzzles, pictures and internet connected media) to be used, reorganizing the concurrent stations to follow each other; some stations were set for group work. All material were at the students' disposal. Three students were delegated as overseers (leaders) and one as teacher's assistant. The remaining 27 students were randomly distributed to three groups, one per station. The teacher made participants ready for the technique during one instructional hour, teacher assistant took pictures, recorded activities and tracked time for the stations. Administration of the instrument-ITMÖ: All 31 students were given the ITMÖ instrument to complete; then data were analyzed. The ITMÖ was developed by initially writing 22 items and expert opinion from biology education, teachers and a language teacher were obtained to evaluate content validity of the items. Based on their comments, the final items were formulated and tested in a pilot study as described above. The final ITMÖ had 16 items, was a 3 Likert type tool. Scale 
reliability was tested using Cronbach's Alpha and found to be 0.987 , suggesting that the items have relatively high internal consistency $(\alpha>0.90)$.

\section{Results}

Stations technique was used in this study to teach Biological Diversity and Protection to $9^{\text {th }}$ grade students taking biology course; and after completion of the activity, an instrument (ITMÖ) was administered to the students to evaluate their satisfaction and motivation. The overall score of the instrument was 2.15. In addition to positive views and satisfaction, some disagreement about the technique was expressed by the students. This was mainly about the activity to be tiresome. Results of $12,13,15$ and 16 showed that the students were motivated, the technique facilitated their learning effectively and filled their knowledge gaps; they liked the activity; disagreed that it was boring (I12, II3 and I15); were relaxed and felt comfortable during the exercise (I7 and I8); they were not unhappy (I9 and I10), on the contrary enjoyed it (I14, average score 2.61). Students enjoyed learning with stations technique, improved their motivation and increased interest in the biology course. Observations also led the authors to the same conclusion; in addition they were happy participating in group work, developed cooperation skills and socialized.

\section{Discussion}

As depicted in Results section, $9^{\text {th }}$ grade biology students are of the opinion that stations technique is beneficial and advantageous, tiresome but on the other hand enjoyable to learn a topic of biology course, namely biological diversity and protection hard to envision, perceive and hard to associate with daily life. It can be successfully used in out-of-class activities, in higher education and graduate education. Our results are in agreement with those of others.

\section{Conclusion}

Stations technique was successfully implemented to teach biological diversity and protection to $9^{\text {th }}$ graders in their biology course. ITMÖ instrument developed by the authors, was used to measure student satisfaction and motivation for the technique. Overall students had positive thoughts about the technique but acknowledged that it was somewhat tiresome. Other positive aspects and strengths were taking responsibility to conclude delegated tasks, work in groups, cooperate, share and attend school better since any unfinished task needed them to return and finalize. Other educators who wish to use the stations technique can conveniently and reliably employ ITMÖ to measure student satisfaction and motivation. 


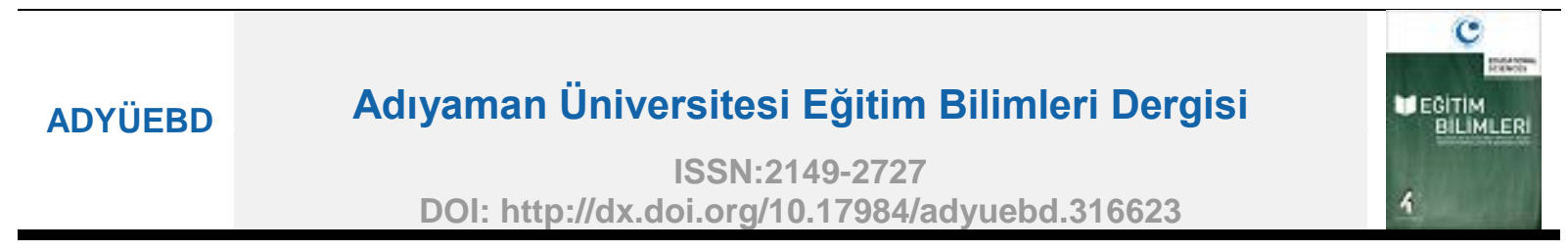

\title{
Dokuzuncu Sınıf “Biyolojik Çeşitlilik ve Korunması” Konusunun İstasyon Tekniği Kullanılarak Öğretilmesi ve Öğrencilerin
}

\section{Uygulamadan Memnuniyeti}

\author{
Duygu KARA EKEMEN, Ali Derya ATIK'²*, Figen ERKOÇ
}

${ }^{1}$ MEB, Şereflikoçhisar Tuz Gölü Anadolu Lisesi, Ankara
${ }_{2}^{2}$ MEB, Genç Osman Anadolu Lisesi, Ankara
${ }^{3}$ Gazi Üniversitesi, Eğitim Fakültesi, Biyoloji Eğitimi Anabilim Dalı, Ankara

MAKALE BILGGI

Makale Tarihçesi:

Alındı 29.05.2017

Düzeltilmiş hali

alındı 19.10.2017

Kabul edildi

20.10.2017

Çevrimiçi

yayınlandı

28.12.2017

\section{ÖZET}

Öğrencilerin pasif olduğu klasik öğretim yöntem ve teknikleri yerine, aktif oldukları, araştırmaya dayalı ve kalıcı öğrenmeyi sağlayan yeni yöntemlerin uygulanması etkili ve kalıcı öğrenme açısından önemlidir. İstasyon tekniği de öğrencilerin öğrenme ve öğretme sürecinde aktif oldukları, araştırarak ve etkili bir şekilde bu sürece dâhil oldukları çalışmaları içerir. Bu çalışma, 2015/2016 Eğitim-Öğretim yılı, bahar döneminde Ankara'nın Şereflikoçhisar ilçesinde Tuz Gölü Anadolu Lisesi'nin 9. sınıf öğrencileri (N = 31) ile yürütülmüştür. Dokuzuncu sınıf öğretim programında yer alan "Biyolojik Çeşitlilik ve Korunması" konusunun öğretilmesinde istasyon tekniği altı ders saatinde farklı etkinlikler düzenlenerek uygulanmıştır. Biyolojik çeşitlilik konusu dönem sonuna geldiği ve üzerinde yeterince durulmadığı ancak bir o kadar da önemli olduğu için tercih edilmiştir. Bu çalışmanın amacı, biyolojik çeşitlilik konularının öğretilmesinde kullanılan istasyon tekniğinden öğrencilerin ne derece memnun olduklarını belirlemeye çalışılmaktır. Bu amaçla araştırıcılar tarafından geliştirilen İstasyon Tekniği Memnuniyet Ölçeği (ITMÖ) uygulanmıştır. Uygulama neticesinde öğrencilerin istasyon tekniğinden genel olarak memnun oldukları, istasyonlarda çalışmayı eğlenceli buldukları, kendilerini rahat hissettikleri bunun yanında tekniği yorucu buldukları belirlenmiştir. İstasyon tekniği öğrencilerin öğrenme sürecine aktif olarak katılımını sağladığı, onların motivasyonlarını arttırdığı ve grup çalışmasını özendirdiği için farklı ders ve konularda da uygulanabilir.

(c) 2017 AUJES. Tüm hakları saklıdır Anahtar Kelimeler: İstasyon tekniği, öğrenme istasyonları, biyolojik çeşitlilik, ortaöğretim

\section{Giriş}

Günümüzde pek çok alanda ortaya çıkan değişiklikler, toplumların ihtiyaçlarının da değişmesine neden olmaktadır. Son yüzyılda teknolojideki gelişmeler, özellikle fen ve matematik alanında etkili olmaktadır (Kayhan ve Koca, 2004). Son 50 yılda gerek bilimsel bilgilerde gerekse bu bilgilerin öğretilmesinde ortaya çıkan gelişmeler nedeniyle fen eğitiminde de önemli değişikler olmuştur (Eşkin ve Bekiroğlu, 2009). Eğitimdeki gelişmeler öğrenci merkezli bir yaklaşım olan yapılandırmacı yaklaşımı ön

\footnotetext{
*Sorumlu yazarın adresi: MEB, Genç Osman Anadolu Lisesi, Ankara e-mail:drada0505@gmail.com
} 
plana çıkarmıştır. Ülkemizde deneye dayalı ve proje tabanlı fen öğretimle birlikte öğrenciyi merkeze alan yapılandırmacı yaklaşım benimsenmiş ve öğretim programları buna göre geliştirilmiştir (Kırkkılıç ve Akyol, 2007).

Genel olarak Biyoloji dersi öğrencilere göre, gerek içeriği gerekse içerdiği yabancı terimlerin ve soyut kavramların fazla olması nedeniyle, oldukça zor bir ders olarak görülmektedir (Kılıç ve Sağlam, 2004). Öğrenciler bu yabancı ve soyut kavramları öğrenmek ve anlamaktan çok ezberleme yoluna gitmektedirler. Bu nedenle öğrencilerin hem Biyoloji dersine karşı olumlu tutum geliştirebilecekleri hem de biyolojideki soyut ve yabancı kavramları rahat anlayabilecekleri, akademik başarılarını arttırabilecekleri uygun yöntem ve tekniklerin seçilmesi çok önemlidir (Ergezen, 1996). Saygın, Atılboz ve Salman'a (2006) göre; 2005 yılından itibaren MEB tarafından uygulamaya konulan yeni öğretim programlarıyla birlikte, öğrenciyi merkeze alan yaklaşım, yöntem ve tekniklerin kullanımı önem kazanmıştır. Ayrıca, öğrencilerin süreç içerisinde entelektüel gelişim ve orijinal buluş yapma yönünde ilerlemeleri beklenebilir. Demir'e (2008) göre öğrencilerin tutumlarını ve başarılarını olumlu yönde etkileyeceği düşünülen yeni uygulamalardan biri de istasyon tekniğidir. Biyolojik çeşitlilik ve korunması birden çok bilim alanını ilgilendirdiğinden çok disiplinli bir yaklaşımla öğretilmesi gerekmektedir. İstasyon tekniği her ne kadar disiplinler arası yaklaşımı birebir uygulayamasa da, en azından istasyonlardaki değişik etkinliklerle ve kullanılan kaynak materyal ile konunun önemini ve birden çok uzmanlık alanını ilgilendirdiğini öğrencilere açıkça gösterebilmekte; bu bağlamda da disiplinler arası becerilerine olumlu katkısı olabilmektedir (Full, Dudley, Koehl, Libby \& Schwab, 2015).

İstasyon tekniği; öğrencilerin konunun hedeflerine ulaşması için tasarlanmış mantıklı, ardışık ve farklı yöntemlerin uygulandığı öğrenme istasyonlarını içermektedir. Öğrenme istasyonlarında bireysel öğrenme farklılıklarının dikkate alınarak öğrencilerin seviyelerine uygun farklı yöntemler seçilmesi, çok sayıda ve farklı araç-gereç ve materyal sunulması ile öğrencilerin derse aktif katılımı sağlanmaktadır. Böylece öğrenciler farklı öğrenme aktivitelerine katılabilmekte, farklı görevler alarak sosyal öğrenme ile hem kendileri öğrenmekte hem de arkadaşlarına öğretebilmektedir. İstasyon tekniğinin amacına ulaşabilmesi için istasyonların çok iyi şekilde tasarlanması, her istasyonun amacının açık şekilde belirlenmesi, araç - gereçlerin doğru seçilmesi ve uygulama sırasında karışıklıklar ve düzensizlikler olmaması için yönergelerin verilmesi ve uygun öğrenciler yönetici / şef olarak görevlendirilmesi çok önemlidir. Her istasyonun bir hedefi olmalı ve öğrenciler bu hedefe ulaşmak için etkinlikleri tamamlamalıdır. Ayrıca bu teknikte öğretmen, sorumluluğu öğrencilere vererek bağımsız çalışma ortamları yaratır ve öz denetimli ortamlarda öğrenciler çeşitli alanlardaki becerilerini geliştirirler. Diğer taraftan istasyon tekniği sayesinde, öğrencilerin sınırlı kaynaklar ile farklı istasyonları gezerek geniş ve kapsamlı içeriği öğrenmeleri kolaylaşır (Manuel, 1974; Breyfogle, Nelson, Pitts, \& Santich, 1976; Kaplan, 1999; Jones, 2007; Tay, 2008).

İstasyon tekniğinde öğretmenin öncelikli görevi danışmanlıktır. Bu teknikte her öğrenci kendine uygun öğrenme yolunu bulur ve kendine uygun öğrenme hızında çalışır. Her öğrenci çalışmanın ağırlık noktasını kendi belirler, kendisini yönlendirir ve 
ilgisine yönelik çalışır. Öğrenme istasyonları, sosyal çalışma biçimlerinin ve öğrenme malzemesinin değişiklikler içermesi nedeniyle idealdir. Öğrenme istasyonlarında tamamlanan ödev ve görevlerin aynı zaman dilimi içerisinde kontrol olanağı sayesinde, öğrencinin kendi çalışmalarını kontrol etmesine olanak verir. Bu çalışma ile her öğrenci aynı zamanda kendi öğrenme stratejilerini öğrenir/deneyim kazanır, uygular ve farklı öğrenme tekniklerini dener. Öğrenme istasyonları kendini yönlendirme için alıştırma alanıdır ve özgüvenin artmasını destekler. Öğretmenlerin ders sırasında öğrencileri ve süreci gözlemleyebilmesi için daha çok zamanları olur (Salzenberg, 2000, akt: Demirörs, 2007). İstasyon tekniği, matematik, fizik, kimya, biyoloji, fen bilgisi, sosyal bilgiler, edebiyat, felsefe, sosyoloji vb. derslerde etkili bir şekilde kullanılabilir (Becker, 1994).

İstasyon tekniğinin üstün yönleri olduğu gibi zayıf yönleri de bulunmaktadır. Bu tekniğin kalabalık sınıflarda uygulanması zor olabilir. Öğretmen kalabalık sınıflarda sınıfın yarısını gözlemci yaparak bu zorluğu aşabilir (Tay, 2008). Bazı öğrenciler grupla çalışmaktan hoşlanmayabilir, kullanılan yöntemlerle öğrenemeyebilir, bu teknikle öğrenmeyi yorucu veya zaman alıcı bulabilir. Dolayısıyla öğrenci başarısı kadar bu yöntemin kullanılmasında da öğrenci memnuniyeti araştırılmalıdır. Bazı konularda uygulamada kullanılacak malzemelerin maliyeti yüksek olabilir; bu durumda sınırlı kaynakla öğrencilerin gruplar halinde istasyonlardaki etkinlikleri yaparak öğrenme ortamı sağlanabilir. Bu yöntem uygulanmadan önce detaylı ve emek isteyen, zaman alıcı bir ön hazırlık yapılması gerekir (Kırkkılıç ve Akyol, 2007).

Son zamanlarda doğal kaynakların, habitatların hızla tahrip edilmesi ve kaybı ile artan çevre sorunları ekosistemdeki birçok tür sayısının ciddî derecede azalmasına; bazı önemli ve endemik türlerin kaybolmasına neden olmaktadır (Dervişoğlu, Menzel, Soran, \& Bögeholz, 2009; http://www.unccdcop12.gov.tr/tr/Home/lcerik/8; http://www.mfa.gov.tr/biyolojik-cesitlilik.tr.mfa). Artık ülkelerin zenginlikleri ifade edilirken sadece sahip oldukları maddi varlıklar değil, aynı zamanda sahip oldukları biyolojik çeşitlilik de dikkate alınmaktadır. Türkiye'nin de taraf olduğu Biyolojik Çeşitlilik Sözleşmesi (UNCBD) bu amaçla geniş katılımlı olarak uluslararası düzeyde yürürlüktedir. Biyolojik çeşitlilik zarar gördüğünde, ekonomik ve sosyal kalkınma; hatta insanlığın geleceği hakkında endişe duyulduğundan 1992'de Rio'da toplanan Dünya Sürdürülebilir Kalkınma Zirvesinde uluslararası işbirliği ile biyolojik çeşitliliğin korunması için harekete geçilmesi amacıyla, 1993 yılında Birleşmiş Milletler günümüzde 195 ülkenin kabul ettiği sözleşmeyi yürütmektedir. Konu o derece önemli ve insanlar için hayati durumdadır ki; Sözleşme ile "Biyolojik çeşitliliğin korunması ve sürdürülebilirlik ilkeleri kapsamında kullanımı ile genetik kaynakların kullanımından doğacak faydanın adil şekilde paylaşımı konularında hazırlanacak ulusal stratejilerin belirlenmesi, eylem planları ve programların geliştirilmesi" karara bağlanmıştır. Oysaki "Biyolojik Çeşitlilik ve Korunması" konusunun orta öğretim programında özellikle bahar döneminin son birkaç haftasında işlenmesi, bu dönemlerde öğrencilerin artan devamsızlık ve ilgisizlikleri, konunun yetiştirilememesi gibi sebeplerle istenilen düzeyde işlenememektedir (Gökyer, 2012; MEB, 2016). Bu çalışmanın bir amacı da 
istasyon tekniğini kullanarak böylesine önemli bir konuya öğrencilerin ilgisini çekmek, kalıcı ve etkili öğrenme sağlamaktır.

Bu araştırmanın başlıca amacı, öğrenilmesi güç bir ders gibi düşünülen biyoloji konularının öğretilmesinde istasyon tekniğinden memnun kalıp kalmadıklarını, biyolojik çeşitlilik konusu kullanılarak ölçmektir. Bu amaca yönelik olarak aşağıdaki sorulara yanıtlar aranmıştır?

1. Öğrencilerin istasyon tekniğine olan memnuniyetleri ne düzeydedir?

2. Öğrenci görüşlerine göre istasyon tekniğinin güçlü yönleri nelerdir?

3. Öğrenci görüşlerine göre istasyon tekniğinin zayıf yönleri nelerdir?

4. İstasyon tekniğinin uygulanmasında yaşanan zorluklar nelerdir?

Araştırmada kullanılan istasyon tekniği ile öğrencilerin derse olan ilgilerini arttırması, zor ve soyut kavramları öğrenmeyi kolaylaştırması, dersi daha zevkli hale getirmesi, ders döneminin sonunda öğrencilerin derse ilgi ve isteklerini özgün etkinliklerle sürekli kılması, öğrencilerin grupla çalışma yapma yeteneklerini geliştirmesi bakımından önemlidir.

\section{Yöntem}

\section{Araştırmanın Modeli}

Araştırma betimsel nitelikte hazırlanmış bir alan ve tarama (survey) araştırmasıdır. Ortaöğretim öğrencilerinin İstasyon Tekniğine Yönelik Memnuniyet Ölçeği (ITMÖ) geliştirme süreci aşağıda verilmiştir. Ölçek geliştirme sürecinde; madde havuzunun oluşturulması, uzman görüşünün alınması, ön deneme aşaması, verilerin toplanması ve verilerin analizi işlem basamakları izlenmiştir (Balcı, 1995; Karasar, 2012). Ölçek geliştirildikten sonra, İstasyon Tekniği uygulanmış ve uygulama yapılan öğrencilerin bu tekniğe olan memnuniyetleri geliştirilen ölçek ile tespit edilmiştir.

\section{Çalışma Grubu}

Bu çalışma 2015/2016 Eğitim ve Öğretim yılında yürütülmüştür. Araştırmanın birinci çalışma grubunu (ölçek geliştirme süreci) Ankara ili Şereflikoçhisar ilçesindeki ortaöğretim kurumlarında 10, 11 ve 12. sınıflarda öğrenim gören 102 kız, 97 erkek, toplam 199 öğrenci oluşturmaktadır. İkinci çalışma grubunu (uygulama süreci) 9/A sınıfı öğrencileri oluşturmaktadır. 9/A sınıfında toplam 31 öğrenci öğrenim görmekte olup bunlardan 17 kız, 14 erkektir.

\section{Veri Toplama Araçları}

Çalışmada veri toplama aracı olarak araştırıcılar tarafından geliştirilen ve detayları verilerin analizi bölümünde açıklanan ITMÖ kullanılmıştır. Dokuzuncu sınıf öğrencilerine dört hafta boyunca 'Biyolojik Çeşitlilik ve Korunması' konusu farklı etkinlikler kurgulanarak İstasyon Tekniği ile işlenmiş ve geliştirilen memnuniyet ölçeği süreç sonunda uygulanmıştır.

\section{Uygulama Süreci}




\section{Uygulama Öncesinde Yapılanlar}

İstasyon tekniği uygulanacak ders saati, kurulacak istasyon sayısı, istasyonlarda uygulanacak etkinlikler Biyoloji dersi öğretim programına göre belirlenmiştir. Sınıf ortamı istasyon tekniği uygulamaları için hazırlanmıştır. Etkinlikler için gerekli olan çalışma kâğıtları, cevap anahtarları, videolar, bulmacalar, resim ve fon kâğıtları hazırlanmıştır.

Bazı istasyonlar konu gereği birbirini takip edecek şekilde sıralanmıştır. Bazı istasyonlar ise sadece grup çalışması şeklinde olup benzer çalışmalar içermektedir. Çalışma kâğıtları, konu ve istasyonların yapısı göz önüne alınarak hazırlanmıştır. Zaman alacak çok fazla yazı içermeyen çalışma kâğıtları düzenlenmiştir. Etkinlikler öğrencileri motive edici, konuya uygun ve karmaşaya neden olmayacak şekilde düzenlenmeye çalışımıştır. Bütün materyaller öğrenci kullanımına sunulmaktadır.

\section{Ön Çalışma}

9/A sınıfı 31 öğrencidir: bunlardan üçü istasyonlarda şef ve biri öğretmen asistanı olarak rastgele belirlenmiştir. Geriye kalan 27 öğrenci rastgele 3 gruba atanmıştır. Çalışma yöntemi şefler ve öğretmen asistanı olarak belirlenen 4 öğrenciye yönerge ile verilerek, bu öğrencilerin ayırt edilmeleri için sarı T-shirt giymeleri istenmiştir. Öğrencilere uygulama öncesinde bir ders saatinde istasyon tekniği hakkında kısaca bilgi verilmiştir. Öğretmen asistanı etkinliklerde süreni takibi, fotoğrafların çekilmesi ve süresi dolan grupların yer değiştirmesi için sinyal vermekle görevlendirilmiştir. Öğrencileri her uygulama saatinde gözlemlemek için gözlem formu kullanılmıştır.

\section{İstasyon Tekniğinin Uygulanması}

Her ders için üç farklı öğrenme istasyonu (A, B ve C) kurulmuştur. Her istasyon için farklı materyaller (çalışma kâğıtları, cevap kâğıtları, öyküler, bulmacalar, videolar vb.) ayrı ayrı hazırlanmıştır. Her grup kendi şefinin başkanlığında çalışmalarını ayrı istasyonlarda belirtilen sürelerde yürütmüştür. Öğrenme istasyonlarının yer değiştirmesi ve süre kontrolü öğretmen asistanı tarafından düzenlenerek takip edilmiştir. Her grup (1, 2 ve 3 . grup) üç farklı öğrenme istasyonundaki (A, B ve C istasyonları) etkinliği sırası ile tamamlamak zorundadır (Şekil 1). Tablo 1'de yer alan istasyonlar ve bu istasyonlarda uygulanan etkinlikler bulunmaktadır. 
Tablo 1. Kurulan İstasyonlar ve İstasyonlarda Kullanılan Etkinlikler, Materyaller ve Uygulama Süresi

\begin{tabular}{|c|c|c|c|}
\hline Ders & $\begin{array}{l}\text { Kurulan } \\
\text { İstasyonlar }\end{array}$ & İstasyonlarda Kullanılan Materyal & $\begin{array}{c}\text { Süre } \\
\text { (dakika) }\end{array}$ \\
\hline \multirow{2}{*}{ 1. Ders } & $\begin{array}{l}\text { Öğrenme } \\
\text { İstasyonları }\end{array}$ & $\begin{array}{l}\text { Üç farklı çalışma kâğıdı, kaynak kitaplar, } \\
\text { internet bağlantılı tabletler }\end{array}$ & 10 \\
\hline & $\begin{array}{l}\text { Kontrol } \\
\text { İstasyonları }\end{array}$ & Çalışma kâğıtlarına ait cevap kâğıtları & 3 \\
\hline 2. Ders & $\begin{array}{l}\text { Öykü } \\
\text { İstasyonları }\end{array}$ & $\begin{array}{l}\text { Fon kartonlar } \\
\text { Yarım bırakılmış üç farklı öykü }\end{array}$ & 10 \\
\hline 3. Ders & $\begin{array}{l}\text { Araştırma } \\
\text { İstasyonları }\end{array}$ & $\begin{array}{l}\text { İnternet bağlantısı olan bilgisayarlar } \\
\text { (bilgisayar sınıfı) } \\
\text { Daha önceden hazırlanmış ve her } \\
\text { bilgisayarların masaüstüne bırakılmış } \\
\text { konulara göre linkler içeren } 3 \text { farklı word } \\
\text { dosyası } \\
\text { Rapor yazılacak kâğıtlar } \\
\text { Konuyla ilgili hazırlanmış kataloglar }\end{array}$ & 40 \\
\hline \multirow{2}{*}{ 4. Ders } & $\begin{array}{l}\text { Video } \\
\text { İstasyonları }\end{array}$ & $\begin{array}{l}\text { Konuyla ilgili videolar } \\
\text { Tabletler }\end{array}$ & 8 \\
\hline & $\begin{array}{l}\text { Bulmaca } \\
\text { İstasyonları }\end{array}$ & $\begin{array}{l}\text { Konuyla ilgili hazırlanmış bulmaca kâğıtları } \\
\text { Bulmacaların cevap anahtarları }\end{array}$ & 12 \\
\hline 5. Ders & $\begin{array}{l}\text { Afiş/Gazete } \\
\text { İstasyonları }\end{array}$ & $\begin{array}{l}\text { Fon kartonlar } \\
\text { Resim kâğıtları } \\
\text { Boya kalemleri }\end{array}$ & 13 \\
\hline 6. Ders & $\begin{array}{l}\text { Tartışma } \\
\text { İstasyonları }\end{array}$ & $\begin{array}{l}\text { Kâğıtlara yazıımış, zarf içinde dört farklı } \\
\text { soru } \\
\text { Çıkarımlarını yazabilecekleri kâğıtlar }\end{array}$ & 13 \\
\hline
\end{tabular}

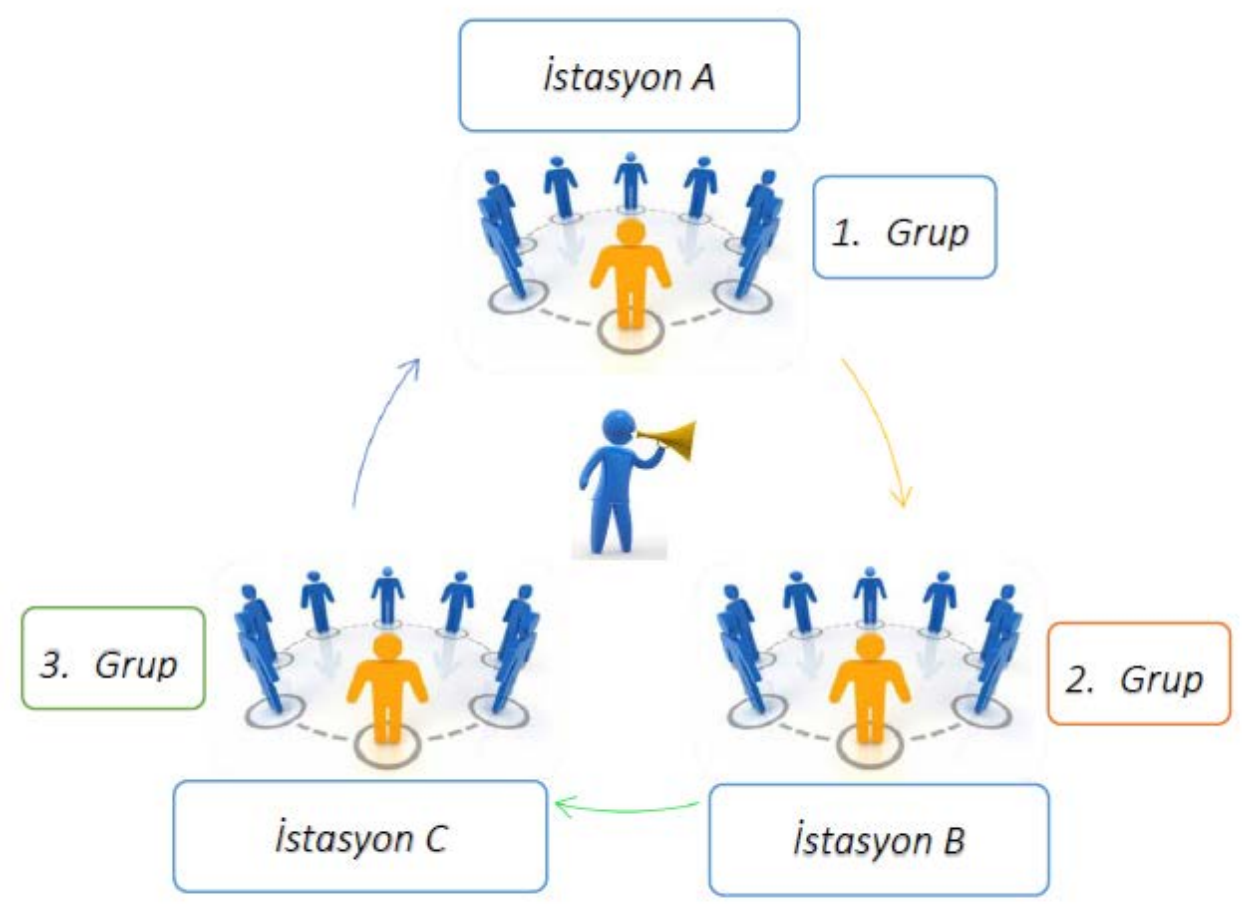

Şekil 1: İstasyon tekniğinin uygulanma süreci 


\section{Ders}

Her grup için üç farklı öğrenme istasyonunda biyolojik çeşitlilik ile ilgili temel kavramları içeren 3 farklı çalışma kâğıdı grup şeflerine teslim edilmiştir. Öğrencilerin çalışma kâğıtlarındaki soruları yanıtlayabilmeleri için istasyonlara kaynak kitaplar, internet bağlantılı tabletler yerleştirilmiştir. Her grup öğrenme istasyondaki 10 dakikalık çalışmasını tamamladıktan sonra öğretmen asistanının işareti ile yer değiştirmiştir. Tüm istasyonlardaki çalışmalar tamamladıktan sonra, verilen yanıtlar önceden hazırlanan cevap kâğıtları kullanılarak, her bir grup şefi tarafından kontrol edilmiştir. Gruplar, öğretmen asistanın verdiği işaret ile bir sonraki istasyonla yer değiştirerek, her bir istasyonda verdikleri yanıtları üçer dakikalık sürede kontrol etmeleri sağlanmıştır.

\section{Ders}

Her grup için üç farklı öykü istasyonu kurulmuştur. Her bir öykü istasyonunda daha önceden renkli fon kâğıtları üzerine biyolojik çeşitliliğin önemini konusundaki öykü girişleri düzenlenmiştir. Her gruptan öykülerin geri kalan kısmını tamamlamaları istenmiş ve öykü istasyondaki 10'ar dakikalık çalışmasını tamamladıktan sonra öğretmen asistanın işareti ile gruplar yer değiştirmiştir. Gruplar tüm istasyonlardaki çalışmalarını tamamladıktan sonra öyküler panoya asıımıştır. Her grup diğer grupların öyküsünü 10 dakikalık sürede incelemiştir.

\section{Ders}

Bilgisayar sınıfı daha önceden düzenlenmiştir. Araştırma istasyonları kurulmuştur. Bilgisayarlarda "Türkiye'deki endemik türler ve nesli tükenme tehlikesi altında olan türler" hakkında araştırma yapılması için kullanılacak bilgisayarlarda Microsoft Office Word dosyalarına çeşitli linkler kaydedilmiştir. Öğrencilerin bu linklerden yararlanmaları beklenmiştir. Bilgisayar sınıfında yer değiştirme olmadığından, öğrenciler grup halinde sabit bir şekilde 25 dakika boyunca çalışmış ve rapor hazırlamışlardır. Kalan 15 dakika boyunca daha önceden hazırlanmış kataloglar gruplara dağıtılmıştır. Öğrenciler kendi raporlarıyla dağıtılan katalogları karşılaştırmıştır. Öğrenciler verdikleri cevapların doğruluklarını kontrol etmişlerdir.

\section{Ders}

Her grup için üç farklı öğrenme istasyonu kurulmuştur. Her bir öğrenme istasyonunda yer alan tablete yaklaşık 8'er dakikalık 'Türkiye'deki endemik türler ve nesli tükenme tehlikesi altında olan türler' hakkında farklı videolar önceden yüklenmiştir. Yaklaşık sekiz dakika boyunca öğrenciler grup şeflerinin tabletten yürüttüğü videoyu izlemiştir. Öğretmen asistanı süreyi takip etmiş ve sinyali verdiğinde öğrenci grupları yer değiştirmiştir. Gruplar tüm istasyonlardaki çalışmalarını tamamladıktan sonra bulmaca istasyonları kurulmuştur. Her bir grup istasyonlarındaki aynı bulmacayı çözmeleri için 12 dakika süre verilmiştir. Bulmaca çözümleri tamamlandıktan sonra grup şeflerine bulmacanın cevap kâğıtları dağıtmıştır. Öğrenciler yer değiştirmeden çözdükleri bulmacayı 4 dakika boyunca kontrol etmiştir.

\section{Ders}


Her grup için üç farklı tartışma istasyonu kurulmuştur. $A$ istasyonunda "Biyolojik Çeşitliliği Tehdit Eden Faktörler Nelerdir?" sorusuyla ilgili; B istasyonunda "Biyolojik Çeşitlilik Türkiye'de Neden Fazladır?" sorusuyla ilgili; C istasyonunda "Biyolojik Çeşitliliği Korumak İçin Neler Yapılmalıdır? Dünyada ve Türkiye'de Biyolojik Çeşitliliği Korumak Amacıyla Görev Alan Kuruluşlar Nelerdir?" sorusuyla ilgili öğrencilerin tartışmaları ve çıkarımda bulunmaları istenmiştir. 13 dakika boyunca öğrenciler sorularla ilgili tartışmışlar ve yaptıkları çıkarımları rapor şeklinde düzenlemişlerdir. Öğretmen asistanı süreyi takip etmiş ve sinyali verdiğinde öğrenci grupları yer değiştirmiştir. Her tartışma istasyonunda öğrenciler diğer grupların yarım bıraktığı yerden devam ederek, sorularla ilgili tartışmışlar ve yaptıkları çıkarımları rapor şeklinde düzenlemişlerdir. Hazırlanan raporlar ders sonunda panolara asılmıştır.

\section{Ders}

Her grup için üç farklı afiş istasyonu kurulmuştur. İstasyon masalarına renkli fon kâğıtlar, resim kâğıtları ve boya kalemleri yerleştirilmiştir. Öğrencilerden "Biyolojik Çeşitlilik ve Çevrenin Önemi” ile ilgili afiş hazırlamaları istenmiştir. Her bir grup istasyonda 13 dakika boyunca afiş üzerinde çalışmışlardır. Öğretmen asistanı süreyi takip edip sinyali verdiğinde öğrenciler yer değiştirmiştir. Her bir grup diğer grubun yarım bıraktığı yerden devam ederek istasyonlardaki afiş hazırlama çalışmasını tamamlamıştır. Hazırlanan afişler ders sonunda panolara asılmıştır.

\section{Uygulama Sonrasında Yapılanlar}

Uygulamalar sonrasında 9/A sınıfındaki 31 öğrenciye ITMÖ uygulanmıştır. Elde edilen veriler aşağıda detayları verilen şekilde analiz edilmiştir.

\section{Verilerin Analizi}

\section{İstasyon Tekniği Memnuniyet Ölçeğinin Geliştirilme Süreci}

Araştırmanın tarama modeli uygulandığı kısmında; istasyon tekniği ile öğretim yapılan öğrencilerin istasyon tekniği ile ders işlemeleri hakkındaki görüşlerini almak; istasyon tekniği ile ders işlenmesinden memnun kalıp kalmadıklarını belirlemek amacıyla İstasyon Tekniği Memnuniyet Ölçeği araştırıcılar tarafından geliştirilmiştir.

Literatür taraması yapılarak ölçekte yer alması muhtemel maddeler yazılmıştır. Kaynak taraması sonunda öğrencilerin istasyon tekniğine yönelik tutumlarını ölçmek amacıyla 22 madde oluşturulmuştur. Uzman (Bir Biyoloji Eğitimi Profesörü, iki Biyoloji Öğretmeni ve iki Türk Dili ve Edebiyatı Öğretmeni) görüşleri alınarak 22 maddenin bir kısmının tutum ifadesi olmaması ve bir kısmının da diğer maddelerle benzerlik göstermesi sebebiyle çıkarılmasına karar verilmiştir. Üçüncü, 4, 11, 13, 19 ve 20. maddeler ölçekten çıkarılmıştır. Böylelikle 16 maddelik 3'lü Likert tipi bir ölçme aracı oluşturulmuştur.

Bu testin ön uygulaması ilk olarak Şereflikoçhisar Tuz Gölü Anadolu Lisesi'nin 10, 11 ve 12. sınıf öğrencilerinden 199 kişi ile yapılmıştır. Farklı sınıflarda ve farklı konularda istasyon tekniği birer ders saatinde uygulandıktan sonra, bu öğrencilerden 
ölçekte yer alan ifadelere katılma düzeylerini belirtmeleri istenmiştir. Ölçeğin yapı geçerliğini belirlemek için Temel Bileşenler Analizi (TBA, Principle Component Analysis) kullanılarak değişkenle arasındaki ilişkilerden hareketle faktör bulmaya yönelik Açımlayıcı Faktör Analizi (AFA, Exploratory Factor Analysis) yapılmışırı. İlk aşamada, verilerin faktör analizine uygun olup olmadığı Kaiser-Meyer-Olkin (KMO) katsayısı ve Barlett Sphericity testi ile kontrol edilmiş; KMO değeri .949 olarak bulunmuştur. Barlett Testi sonucu istatistiksel olarak anlamlı bulunmuştur $(6366,088$; $p<0.01)$. Bu durum çalışma grubu verilerinin faktör analizinin yapılması için uygun ve yeterli olduğunu göstermiştir (Weathersby ve Freyberg, 2008; Young ve Pearce, 2013).

Tablo 2. ITMÖ'ne ait KMO ve Barlett Testi Değeri

\begin{tabular}{lcr}
\hline KMO & $X^{2}$ &, 949 \\
Barlett Testi & df & 6366,088 \\
& $p$ & 120 \\
\hline$X^{2}=$ Ki-kare $d f=$ serbestlik derecesi, $P=$ istatistiksel anlamllk &, 000 \\
\hline
\end{tabular}

$X^{2}=$ Ki-kare,$d f=$ serbestlik derecesi, $p=$ istatistiksel anlamlılık

Bu çalışmayı desteklemek ve faktör sayısına doğru karar verebilmek amacıyla faktörlerin özdeğerlerine (eigenvalue) dayanan Scree sınaması grafiği incelenmiştir. Bu grafik ölçekte yer alan maddelerin tek faktörde toplanabileceğini göstermektedir (Şekil 2). Scree sınaması sonrasında ölçekte yer alacak maddelerin faktör yük değerleri incelenmiş ve 16 maddenin de faktör yük değerinin 0,45'den büyük olduğu görülmüştür (Tablo 3). Bu durumda 16 maddenin de ölçekte kalmasına karar verilmiştir.

Tablo 3. ITMÖ Yer Alan Maddelerin Faktör Yükleri

\begin{tabular}{ccccccccc}
\hline $\begin{array}{c}\text { Madde } \\
\text { No } \\
\text { Faktör } \\
\text { Yükü }\end{array}$ & 2 & 9 & 10 & 14 & 17 & 12 & 8 & 6 \\
\hline $\begin{array}{c}\text { Madde } \\
\text { No }\end{array}$ & 1 & 22 & 21 & 7 & 5 & 16 & 18 & 15 \\
$\begin{array}{c}\text { Faktör } \\
\text { Yükü }\end{array}$ & .922 & .902 & .900 & .889 & .871 & .857 & .848 & .814 \\
\hline
\end{tabular}




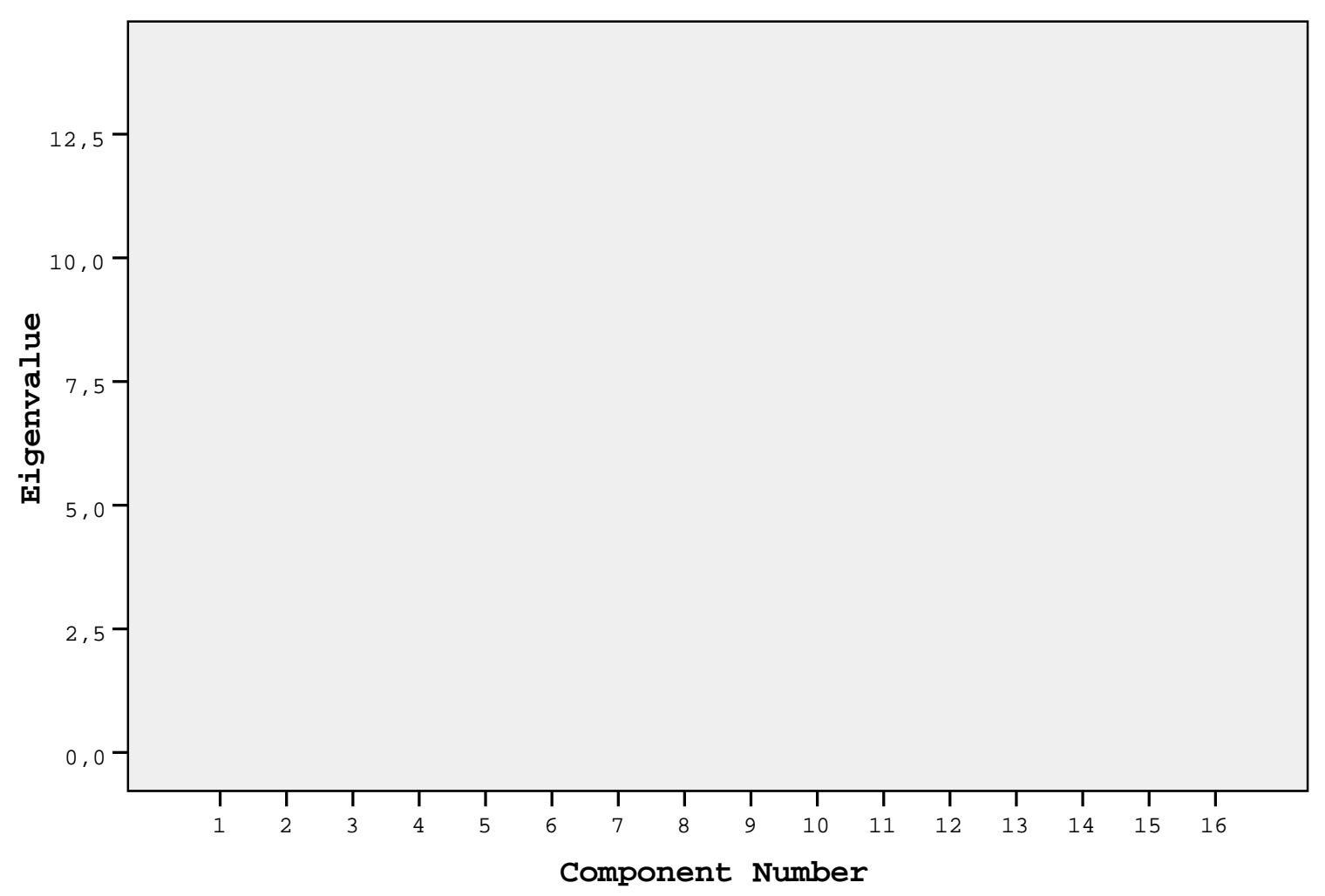

Şekil 2. Faktör öz değerlerine ait çizgi grafiği (Scree sınama grafiği)

Elde edilen verilere göre açıklanan varyans oranı $(\% 83,71)$, hedeflenen varyans oranının (\%67) üzerindedir. Faktör analizi sonucunda öz değeri 1'den büyük olan bir faktör ortaya çıkmıştır (Tablo 4).

Tablo 4. ITMÖ Faktörlerin Varyans Açıklama Yüzdesi

\begin{tabular}{cccc}
\hline Faktörler & $\begin{array}{c}\text { Eigenvalue } \\
\text { (Özdeğer) }\end{array}$ & $\begin{array}{c}\text { Varyans Açıklama } \\
\text { Yüzdesi (Toplam) }\end{array}$ & $\begin{array}{c}\text { Varyans Açıklama } \\
\text { Yüzdesi (Kümülatif) }\end{array}$ \\
\hline F1 (1. Faktör) & 13,393 & 83,708 & 83,708 \\
\hline
\end{tabular}

Ölçeğin Cronbach's Alpha güvenirlik katsayısı 0,987 olarak hesaplanmış olup; bu durum ölçeğin güvenirliğinin mükemmel $(\alpha>0,90)$ olduğunu göstermektedir (Tablo $5)$.

Tablo 5. ITMÖ'ye Illişkin İç Tutarlık Katsayıları

\begin{tabular}{ccc}
\hline Faktörler & Madde Sayısı & Cronbach's Alpha Katsayısı \\
\hline Ölçeğin Tamamı & 16 & .987 \\
\hline Sonuç olarak; 16 madde içeren 3'lü Likert tipi İstasyon Tekniği Memnuniyet \\
Ölçeği geliştirilmiştir.
\end{tabular}




\section{Bulgular}

$\mathrm{Bu}$ araştırmada biyolojik çeşitlilik konusunun öğretilmesinde istasyon tekniği uygulanmış ve öğrencilerin bu teknikten ne düzeyde memnun kaldıkları tespit edilmiştir. İstasyon tekniği uygulandıktan sonra, öğrencilerin bu tekniğe olan memnuniyet düzeyleri, araştırıcılar tarafından geliştirilen memnuniyet ölçeği kullanılarak belirlenmiştir. Ölçek; 16 maddeden oluşan, tek faktörlü, geçerliği ve güvenirliği test edilmiş, özgün bir ölçektir. ITMÖ ile istasyon tekniği uygulanan 9/A sınıfı öğrencilerinin bu teknikten memnun olup olmadıkları, istasyon tekniğine yönelik tutumları, öğrencilerin istasyon tekniği ile ders işlenmekten zevk alıp almadıkları uygulamalar bittikten sonra ITMÖ ile ölçülmeye çalışılmıştır.

ITMÖ ile elde edilen betimsel istatistikler aşağıdaki Tablo 6'te gösterilmiştir. İstasyon tekniği uygulanan öğrencilerin vermiş oldukları cevaplara göre her tutum maddesine ait frekanslar, yüzde değerleri ile her maddeye ait ortalama tutum puanları aşağıda sunulmuştur.

Tablo 6. Öğrencilerin İstasyon Tekniğine Yönelik Tutumları

\begin{tabular}{|c|c|c|c|c|c|}
\hline İstasyon Tekniği Memnuniyet Ölçeği & $\frac{\triangleright^{\circ}}{4}$ & 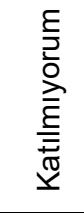 & 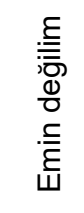 & 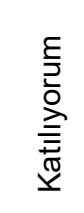 & $\bar{x}$ \\
\hline \multirow[t]{2}{*}{ 1. Arkadaşlarımla beraber istasyonlarda çalışmak hoşuma gider. } & $f$ & 3 & 6 & 22 & \multirow{2}{*}{2,61} \\
\hline & $\%$ & 9,7 & 19,4 & 71,0 & \\
\hline \multirow[t]{2}{*}{ 2. İstasyon tekniğini severim. } & $\mathrm{f}$ & 5 & 4 & 22 & \multirow{2}{*}{2,55} \\
\hline & $\%$ & 16,1 & 12,9 & 71,0 & \\
\hline \multirow[t]{2}{*}{ 3. İstasyonlarda çalışırken arkadaşlarımdan yeni bilgiler öğrenirim. } & $f$ & 5 & 4 & 22 & \multirow{2}{*}{2,55} \\
\hline & $\%$ & 16,1 & 12,9 & 71,0 & \\
\hline \multirow[t]{2}{*}{ 4. İstasyonlarda çalışırken eksiklerimi kapatamam. } & $f$ & 23 & 6 & 2 & \multirow{2}{*}{1,32} \\
\hline & $\%$ & 74,2 & 19,4 & 6,5 & \\
\hline \multirow[t]{2}{*}{ 5. İstasyon tekniğinden nefret ederim. } & f & 23 & 5 & 3 & \multirow{2}{*}{1,35} \\
\hline & $\%$ & 74,2 & 16,1 & 9,7 & \\
\hline \multirow[t]{2}{*}{ 6. ̇̀stasyon tekniği ile ders işlendiğinde zaman daha çabuk geçiyor. } & f & 3 & 5 & 23 & \multirow{2}{*}{2,65} \\
\hline & $\%$ & 9,7 & 16,1 & 74,2 & \\
\hline \multirow[t]{2}{*}{ 7. İstasyon tekniği ile ders işlediğimiz zaman çok gergin olurum. } & f & 23 & 5 & 3 & \multirow{2}{*}{1,35} \\
\hline & $\%$ & 74,2 & 16,1 & 9,7 & \\
\hline \multirow[t]{2}{*}{ 8. ̇̇stasyon tekniği ile ders işlerken kendimi daha rahat hissederim. } & f & 3 & 4 & 24 & \multirow{2}{*}{2,68} \\
\hline & $\%$ & 9,7 & 12,9 & 77,4 & \\
\hline \multirow[t]{2}{*}{ 9. İstasyon tekniği ile ders işlemek beni mutsuz ediyor. } & f & 24 & 6 & 1 & \multirow{2}{*}{1,26} \\
\hline & $\%$ & 77,4 & 19,4 & 3,2 & \\
\hline \multirow[t]{2}{*}{ 10. İstasyonlarda çalışmak çok eğlencelidir. } & f & 1 & 6 & 24 & \multirow{2}{*}{2,74} \\
\hline & $\%$ & 3,2 & 19,4 & 77,4 & \\
\hline \multirow[t]{2}{*}{ 11. İstasyonlarda çalışmak çok yorucudur. } & f & 3 & 5 & 23 & \multirow{2}{*}{2,65} \\
\hline & $\%$ & 9,7 & 16,1 & 74,2 & \\
\hline \multirow{2}{*}{$\begin{array}{l}\text { 12. İstasyon tekniğinde yaptığımız etkinlikleri ders dışında da } \\
\text { konuşurum. }\end{array}$} & $\mathrm{f}$ & 3 & 5 & 23 & \multirow{2}{*}{2,65} \\
\hline & $\%$ & 9,7 & 16,1 & 74,2 & \\
\hline \multirow[t]{2}{*}{ 13. İstasyonlarda çalışırken kendimi işe yaramış hissederim. } & $f$ & 3 & 6 & 22 & \multirow{2}{*}{2,61} \\
\hline & $\%$ & 9,7 & 19,4 & 71,0 & \\
\hline
\end{tabular}


Tablo 6'nın devamı

\begin{tabular}{llllll}
\hline $\begin{array}{l}\text { 14. İstasyonlarda kendi çabalarımla birşeyler öğrenmem beni mutlu } \\
\text { eder. }\end{array}$ & $\mathrm{f}$ & 3 & 6 & 22 \\
\cline { 2 - 5 } & $\%$ & 9,7 & 19,4 & 71,0 \\
\hline 15. İstasyon tekniği çok sıkıcıdır. & $\mathrm{f}$ & 22 & 4 & 5 \\
\cline { 2 - 5 } & $\%$ & 71,0 & 12,9 & 16,1 \\
\hline 16. İstasyonlarda çalışmak bana çok zor gelir. & $\mathrm{f}$ & 22 & 6 & 3 \\
\cline { 2 - 4 } & $\%$ & 71,0 & 19,4 & 9,7 \\
\hline Toplam ortalama & & & & & 2,15
\end{tabular}

Bu bulgulara dayanarak istasyon tekniği uygulanan öğrencilerinin;

- Eksik oldukları noktaları kapatabildikleri,

- İstasyonlarda çalışmayı yorucu buldukları,

- İstasyon tekniğini sevdikleri ve beğendikleri,

- İstasyonlarda çalışmayı eğlenceli buldukları,

- İstasyonlarda arkadaşlarıyla çalışmaktan hoşlandıkları,

- İstasyonlarda çalışırken kendilerini işe yarar hissettikleri,

- Kendi çabalarıyla yeni bilgiler öğrenmekten hoşlandıkları,

- İstasyonlarda çalışırken kendilerini daha rahat hissettikleri,

- İstasyonlarda çalışırken kendilerini daha mutlu hissettikleri,

- İstasyonlarda çalışırken arkadaşlarından yeni bilgiler öğrenebildikleri,

- İstasyonlarda çalışırken ders boyu zamanın nasıl geçtiğini anlamadıkları,

sonuçlarına ulaşılmıştır.

İstasyon tekniği hakkında öğrencilerin olumlu görüşlerinin yanında olumsuz görüşleri de ortaya çıkmıştır. İstasyonlarda çalışmanın öğrencilere yorucu geldiği gözlenmiştir. Buna rağmen ölçeğin ortalama tutum puanı 2,15 olarak hesaplanmıştır. Bir, 2, 3 ve 6 . maddelerde toplam puan > 2,50 olması istasyon tekniği ile eksikliklerini kapatıp, yeni bilgiler öğrenebildiklerini, başarılı olabildiklerini ayrıca tekniği sevdiklerini ve zamanın daha iyi geçtiğini göstermektedir. Dördüncü ve 5. maddelere ise 23 öğrenci katılmadıklarını beyan etmişlerdir, bu öğrenciler eksikliklerini istasyon tekniği ile kapattıklarını ve nefret etmediklerini bildirmiştir. Diğer taraftan 12. ve 13. maddelerdeki tekniği faydalı bulmaları da (ortalama puanlar 2,65 ve 2,61) 2, 3 ve 6 . maddedeki olumlu görüşlerini destekler özelliktedir. On beşinci maddedeki ortalama 1,45 puan da tekniğin sıkıcı olduğu görüşüne katılmadıklarını göstermektedir. Yedinci ve 8. maddelerin puanlarından da kendilerini rahat hissedip gerilmedikleri anlaşılmaktadır. Benzer durum 9. ve 10. maddelere verdikleri ortalama puanlar ile teknikten mutsuz olmadıkları; aksine eğlendikleri anlaşılmaktadır (1,26 ve 2,74 ortalama puanlar). Ortalama 2,61 puan ile öğrenciler 14. maddede de teknikten mutlu olduklarını teyit etmektedir. Bu bulgulara dayanarak istasyon tekniği kullanılarak yapılan öğretimden öğrencilerin zevk aldıkları, istasyon tekniğinin derse yönelik ilgi ve motivasyonu 
arttırdığı, öğrencilerin istasyon tekniğini sevdiği ve beğendiği; bununla beraber yorucu bulduğu sonucuna ulaşılmaktadır. Uygulama sürecinde yapılan gözlemlerde de öğrencilerin bu teknikten memnun kaldıkları, grup çalışmalarına istekli katıldıkları, işbirliği yapma becerilerini arttırdıkları ve sosyalleştikleri saptanmıştır.

\section{Tartışma ve Sonuç}

Yukarıda Bulgular bölümünde verildiği gibi uygulama öğrencileri, Biyoloji ders konularından kavraması zor ve günlük hayat ile doğrudan ilişkilendirmeleri çok kolay olmayan biyolojik çeşitlilik konusunda istasyon tekniğini faydalı, yorucu ancak zevkle öğrenmelerini sağladığı görüşündedir. Zentall ve Zentrall'e (1976) göre istasyon tekniği öğrencilerin kendilerine olan güveni sağlayarak, onlarda başarma gücünü geliştirerek birlikte çalışmayı öğretiyor. Başkalarının düşünce ve görüşlerine hoş görüyle bakabiliyor ve onları dinleyebiliyorlar. Toplumsallaşmalarını ve doğru iletişim kurmalarını bu teknik sağlayabiliyor. Sönmez'e (2007) göre öğrenciler istasyon tekniğiyle ders işlerken istendik hedef davranışları daha kolay kazanabilirler. Üstelik dersten zevk alıyorlar, sıkılmıyorlar, hoşlarına gidiyor, dikkatleri dağılmıyor ve oynayarak öğrenebiliyorlar. Oyun, öğrenme için önemli ve etkin bir araçtır. Öğrenciler, dersten zevk aldıkları zaman, etkin bir şekilde derse katılmakta, ortamdan hoşlanmaktadırlar. Murphy ve Decker'a (1989) göre istasyon tekniğiyle yeni ve özgün düşünceler, ürünler ortaya konulabilir. Bu teknikle yaratıcı düşünme geliştirilebilir. Bu iş, sınıfta arkadaşlarıyla birlikte yapılabilir. Öğrenciler, öğretmenden, anne, baba ve büyüklerden yardım almadan kendi başlarına iş yapmayı öğrenebilirler. Böylece kendilerine olan güvenleri artabilir. Bu da çok önemli kazanımlardan biridir. Oysa eğitim sistemimizde, bu tür etkinlikler genellikle eve ödev olarak verilir. Bu ödevleri de çoğunlukla anneler, babalar, büyükler yapar. Çocuk hiçbir emek harcamadan not alabilmektedir. Bu, onun "hazıra konmasına", başkasının yaptıklarıyla not almasına, zamanla her şeyi başkalarından beklemesine, öz güvensiz bir kişilik oluşturmasına neden olabilir. İstasyon tekniğinin üstün yönlerini ifade eden yukarıdaki bulgular ile araştırmamızdan elde edilen bulgular birbirini destekler niteliktedir.

Öğrenme istasyonları (istasyon tekniği), Türkiye'deki öğrenciler için çok yeni bir yöntemdir. İstasyon tekniği, öğretmeni pasif hale getirmek yerine öğretmeni rehber, yol gösteren konumuna getirmektedir (Demirörs, 2007; Jones, 2007). İstasyon tekniği ile öğrenciler, öğretmenleri rehberliğinde bilgiye daha kolay ulaşabilmekte, kendi çabalarıyla bilgi edinmekte, yaşantıları ile daha kalıcı öğrenme sağlayabilmektedirler. Öğrencilerde konulara karşı merak uyandıran bir teknik olmasından, öğrenme ortamlarını daha eğlenceli hale getirmesinden, öğrenciler tarafından sevilmesi ve beğenilmesinden dolayı, özellikle dönem sonlarından artan öğrenci devamsızlıklarını azaltmada, öğrencileri araştırarak öğrenmeye teşvik etmekte yararlı olacağı düşünülmektedir. Öğrenci, bir sonraki istasyonda ne yapacağını, sonraki hafta hangi etkinlikte nasıl görev alacağını merak edeceğinden, grup arkadaşlarıyla yaptığı çalışmaları yarım bırakmamak için derslere daha az devamsızlık yapar hale gelecektir. Derse tam katılımın sağlanamadığı durumlarda uygulanabilecek bir tekniktir. Rastgele, heterojen gruplara ayrılan sınıfta her öğrenciye istasyonlarda bir görev düştüğünden 
çalışmayı tamamlayabilmek için gruptaki görevini de tamamlamak durumundadır. Böylece, öğrencilerin derse katılımı sağlanabilmektedir.

Tekniğin başarılı uygulanabilmesi için hedef kitleler olarak, yükseköğretim kurumlarındaki öğretmen adaylarına, daha sonra hizmet içi eğitim kursları ile öğretmenlere, daha sonra öğrencilere istasyonlarda öğrenme tekniğinin nasıl uygulandığı, nasıl hazırlandığı, yararlarının neler olduğu açıklanmalıdır. Avrupa ülkelerinde yapılan bir araştırmada (Lindemann-Matthies, Constantinou, Lehnert, Nagel, Raper, \& Kadji-Beltran, 2011) öğretmen adaylarının sınıf-dışı eğitimi istasyon tekniği kullanarak aldıklarında, biyolojik çeşitlilik öğretiminde kendilerini daha yeterli gördükleri ve grup çalışmasıyla paylaşılan aktivite ile konu hakkındaki bilgi eksiklerinin tamamlanmasından çok fazlasını edindikleri; tekniği göreve başladıklarında kullanacakları sonucuna varılmıştır. İstasyonlarda çalışan öğrenciler kendi çabalarıyla öğrenebildiğini, öğrendiklerini unutmadığını ve öğrendiklerinin daha kalıcı olduğunu gördükçe okula ve derse daha da motive olacağından, öğrencilerin akademik başarısı da yükselebilecektir. Öğretmen ise tekniğin uygulanmasında sınıf yönetimi konusunda daha az davranışsal problemle karşılaşabilir.

Araştırmada, öğrencilere istasyon tekniği kullanılarak 'Biyolojik Çeşitlilik ve Korunması' konusunun öğretilmesi sağlanmıştır. Öğrencilerin istasyon tekniğinden memnun kaldıkları, istasyon tekniğini sevdikleri, istasyonlarda arkadaşlarıyla çalışmaktan memnun oldukları, kendi çabalarıyla yeni bilgiler öğrenmek ve derste aktif olmaktan, yeni materyaller kullanmak ve değişik etkinlikler görmekten hoşlandıkları, biraz yorucu olsa da derste zamanın nasıl geçtiğini anlamadıkları, başka konu ve derslerde de istasyon tekniği ile çalışmayı istedikleri, dersin eğlenceli ve keyifli geçtiği, verilen görevlerde arkadaşlarıyla fikir alış-verişinde bulunmaktan hoşlandıkları sonuçlarına ulaşılmıştır.

Daha önceki yıllarda istasyon tekniği ile ilgili, farklı eğitim kurumları ve düzeylerde araştırmalar yapılmıştır. Chance (1974), istasyon tekniğinin öğrencilere, derse daha aktif katılım imkânı sağladığını; öğrencilerin yaparak yaşayarak öğrendiklerini bildirmiştir. Vacca (1976), tekniğin öğrencilerin öğrenme rehberi olma özelliğini vurgulamıştır. Strauber (1982), istasyon tekniğinin öğrenme ortamlarının bireyselleştirilmesini sağladığını belirtmiş; Sunday (1979) ise, tekniğin sınıf yönetimine ve öğretim programlarının uygulanmasına katkısına dikkat çekmiştir. Howatson (1971), istasyon tekniğinin öğrencilerin yaratıcılıkları, sosyal gelişimleri, benlik kavramları, okula karşı tutumları üzerinde de anlamlı bir etki yaptığını bildirmiştir. Schurr (1995), öğrencilerin sorumluluk alma becerilerini geliştirdiğini, daha cesaretli ve kendi öğrenmelerini kontrol etmelerini sağladığını, öğrenme isteklerini artırdığını belirtmiştir. Robert (1999), istasyon tekniğinin yeni ve zor konuların öğrenilmesinde etkili olduğunu ve öğrencilerin fen derslerine karşı olan tutumlarını da olumlu yönde etkilediğini belirtmiştir. Öğretmen, öğrenmeyi en yüksek düzeyde sağlayabilmek için sınıf ortamını düzenlemektedir; ancak öğrenme öğrencinin işidir. Öğrencilerin bireysel olarak öğrenme durumları farklı olduğundan, birçok faktörle birlikte sınıf ortamının düzenlenmesi öğrenmeye etki etmektedir. Grup çalışmalarında grup içi veya gruplar 
arası etkileşimler bazı bireylerde öğrenmeyi desteklerken bazı bireylerde ise öğrenmeyi engelleyebilmektedir (Tanner, 2013).

Türkiye'de de istasyon tekniğine 2000'li yıllarda ilgi artmış; alana katkı sağlayan araştırmalar yürütülmüştür. Erdağı ve Önel (2015), tekniği, fen ve teknoloji dersinde uygulamış; öğrencilerin grupla çalışmaktan zevk aldıklarını, istasyon tekniğinin öğrencilerin derse olan ilgisini arttırdığını bildirmiştir. Ayrıca öğrencilerin istasyon tekniğini sevdiklerini ve bu yüzden başka derslerde de uygulanmasını istediklerini belirtmiştir. Maden ve Durukan (2010) da benzer olarak derse olan ilgiyi Türkçe dersinde arttırdığını ve çeşitli alanlardaki becerilerini geliştirmesine yardımcı olduğunun belirtmiştir. Demir (2008), istasyon tekniği ile ders işlemenin ilgiyi arttırmanın yanında, sınıf ortamında demokratik bir ortam yaratmaya yardımcı olduğunu, daha keyifli ve zevk alarak ders işlemelerini sağladığını bildirmiştir. Demirörs (2007), istasyonlarda öğrenme gerçekleştiren öğrencilerin istasyon tekniğine yönelik olumlu tutum geliştirdiklerini açıklamıştır. Mergen (2011), istasyon tekniğinin öğrencilerin ilgisini çektiğini ve öğrenme isteklerini artırdığını gözlemlemiştir. Ocak (2010), öğrencilerin istasyon tekniği ile çalışma yapmalarının kendilerine olan güvenlerini artırdığını belirtmiştir. Porter (2014), bu yöntemle ders işlemenin öğrenciler tarafından beğenildiğini, eğlenceli bulunduğunu belirtmiştir. Ayrıca öğrencilerin istasyonlarda çalışırken daha az davranış problemi sergilediğini gözlemlemiştir. Lebak (2005), istasyon tekniğinin öğrencilerin fen dersine katılımını ve fen dersine karşı olan ilgilerini artırdığını; öğrencilerin birbirileriyle, öğretmenleriyle ve araç-gereçlerle olan etkileşimlerini artırdığını belirtmiştir. Full vd. (2015) ile Ratnayaka (2017) tekniğin yükseköğretim lisans ve lisansüstü düzeyde de özellikle laboratuvar derslerinin ve arazi çalışması mümkün olmadığı durumlarda kampüste öğrenme istasyonları kullanılarak bitkilerin öğretiminde başarıyla kullanılabileceğini göstermiştir.

Furutani (2007), istasyon tekniğinin öğrenci intiyaçlarına yönelik bir teknik olduğunu ve öğrenciler tarafından beğenilen bir teknik olduğu sonucuna ulaşmıştır. Batdı ve Semerci (2012), öğrencilerin derse olan motivasyonunu arttırdığını, bilgilerini yeniden yapılandırmalarına ve öğrenmelerinin kalıcılığına olumlu yönde katkı sağladığını vurgulamıştır. Kocamanoğlu (2014), öğrenme merkezlerinin öğrencilerin tamamı tarafından sevildiğini gözlemlemiştir. Avcı (2015), istasyon tekniğinin öğrencilerin İngilizce dersine olan ilgilerini ve tutumlarını arttırdığını gözlemlemiştir. Gerçek (2010), tekniğin ilginç ve diğer modellerden farklı olduğunu, öğrencilerin bu modelle ders işlemekten keyif aldıklarını belirtmiştir. Alacapınar (2009), öğrencilerin istasyon tekniği ile ders işlemeyi sevdikleri sonucuna ulaşmıştır. Yapılan çalışma sonucunda istasyon tekniğinin öğrencilerin düşünme becerilerini ve yaratıcılıklarını geliştirdiği, öğrencileri birlikte çalışmaya yönlendirdiği sonucuna ulaşmıştır. Eilks (2002), öğrencilerin ders motivasyonunun arttığını, çekingen öğrencilerin derse daha kolay dâhil olduğunu, işbirliğine dayalı öğrenmeyi desteklediğini belirtmiş; ancak uzun konular örneğinde olduğu gibi, her ünitede uygulanamaya müsait olmayabileceğini, monotonluğa sebep olabileceğinden ünite bitene kadar sınıf mevcudunun sabitliğinin sağlanamayabileceğini belirtmiştir. Tanner (2013) de grup büyüklüğünün istasyonlardaki uygulamanın başarısı için önemine vurgu yapmış; gruptaki her üyeye 
görev dağılması yapılmasının ve açıkta öğrenci kalmayarak herkesin aktif katılımının önemli olduğuna, öğrencilerde izole edime duygusu gelişmesinin önüne geçilmesine, dikkat çekmiştir.

$\mathrm{Bu}$ araştırmada istasyon tekniği; öğrenciler tarafından sevilmiş, eğlenceli ve keyifli bulunmuştur. Öğrenciler; istasyon tekniği ile ders işlerken zamanın nasıl geçtiğini anlamamışlar ve kendi çabalarıyla yeni bilgiler öğrenmek, arkadaşlarıyla birlikte çalışmak, derste oturmak yerine dolaşarak etkinlikler yaptıklarından, derse karşı olan ilgilerini artırmıştır. Ayrıca öğrencilerin istasyon tekniğine karşı olumlu tutum geliştirmelerini sağlamıştır. Araştırma sonucunda elde edilen bulgular daha önceki ve 2000'li yıllarda yapılan çalışmaların sonuçlarıyla benzerlik göstermektedir. Sonuç olarak 9. sınıf Biyoloji dersinde 'Biyolojik Çeşitlilik ve Korunması' konusunun öğretilmesinde istasyon tekniği kullanılan bu araştırmada öğrencilerin istasyon tekniğine karşı olumlu yönde tutum geliştirdikleri gözlenmiştir.

Öğrencilerin istasyon tekniğine karşı olumlu tutumları öğrenmeyi kolaylaştırmaktadır. İstasyon tekniğinde bireysel çalışmaların yanında grup çalışması da önemlidir. Öğrencilerin grup içinde ve gruplar arasında saygılı olma, farklı düşüncelere karşı hoşgörülü olma, etkili iletişim kurabilme, yapılacak iş ve işlemlerde sorumluluk alabilme, paylaşabilme gibi becerilerinin geliştirilmesinde istasyon tekniğinden yararlanılabilir. İstasyon tekniği iletişim kurmakta zorlanan öğrencilerin gelişimine yardımcı olabilir. Öğrencilerden özgün fikirler geliştirmesi istendiğinde ve yaratıcılıklarının geliştirilmesinde istasyon tekniğinden yararlanılabilir. Günümüz eğitim felsefesine uygun olan istasyon tekniğinde öğretmen rehber, yol gösterici ve öğrenci öğrenme sürecinde aktif olduğundan, kendi çabaları ile öğrendiğinden öğrencilerde kalıcı öğrenmeyi arttırabilir. İstasyon tekniğinin olumlu yanları dikkate alındığında grup çalışmasına uygun olan konuların öğretilmesinde ve farklı derslerde kullanılması önerilmektedir. Bu çalışmada geliştirilen ölçek, ileride yapılacak çalışmalarda öğrencilerin istasyon tekniğinden memnuniyetini ölçmek amacıyla kullanılabilir. Ayrıca istasyon tekniğinin öğrencilerin akademik başarılarını nasıl etkilediği, kalıcı öğrenmeyi sağlayıp sağlamadığını inceleyen araştırmalar yapılması öneri olarak sunulabilir.

\section{Kaynaklar}

Alacapınar, G. F. (2009). İstasyon tekniği ile ders işlemeye yönelik öğrenci görüşleri. Abant İzet Baysal Üniversitesi Eğitim Fakültesi Dergisi, 9(1), 137-147.

Avcı, H. (2015). Ingilizce öğretiminde istasyon tekniği kullanımının akademik başarıya, tutumlara ve kalıcılığa etkisi. Yüksek Lisans Tezi. Fırat Üniversitesi Eğitim Bilimleri Enstitüsü, Elazığ.

Batdı, V. \& Semerci, Ç. (2012). Derslerde istasyon tekniği uygulamasının yansıtıcı sorgulaması. Bartın Üniversitesi Eğitim Fakültesi Dergisi, 1(1), 190-203.

Becker, H. (1994). Chemiedidaktische entwicklungen in der bundesrepublik. Deutschland: Peter Lang.

Breyfogle, E., Nelson, S., Pitts, C. \& Santich, P. (1976). Creating a learning environment: a learning center handbook. California: Goodyear. 
Chance, L. L. (1974). Using a learning stations approach to vocabulary practise. Journal of Reading, 18(3), 244-246.

COP 12 (2016). 12. Taraflar Konferansı Biyolojik çeşitliliğin önemi. http://www.unccdcop12.gov.tr/tr/Home/lcerik/8 adresinden Nisan 2017 tarihinde erişilmiştir.

Demir, M. R. (2008). İstasyonlarda öğrenme modelinin hayat bilgisi dersindeki üst düzey beceri erişisine etkisi. Yüksek Lisans Tezi, Hacettepe Üniversitesi Sosyal Bilimler Enstitüsü, Ankara.

Demirörs, F. (2007). Lise 1. sınıf öğrencileri için ohm yasası konusunda öğrenme istasyonlarının geliştirilmesi ve uygulanması. Yüksek Lisans Tezi, Hacettepe Üniversitesi Fen Bilimleri Enstitüsü, Ankara.

Dervişoğlu, S., Menzel, S., Soran, H. \& Bögeholz, S. (2009). Değerler, inançlar ve problem algısının biyolojik çeşitliliği korumaya yönelik kişisel normlara etkisi. Hacettepe Üniversitesi Eğitim Fakültesi Dergisi, 37, 50-59.

Eilks, I. (2002). Learning at stations secondary level chemistry lessons. Science Education International, 13 (1), 11-18.

Erdağı, S. \& Önal, A. (2015). İstasyon tekniğinin uygulandığı fen ve teknoloji dersine ilişkin öğrenci görüş ve performanslarının değerlendirilmesi. e-Kafkas Eğitim Araştırmalar Dergisi, 2 (1), 28-38.

Eşkin, H. \& Bekiroğlu, F. (2009). Investigation of a pattern between students' engagement in an argumentation and their science content knowledge. A case study. Eurasia Journal of Mathematics, Science and Technology Education, 1(5), 63-70.

Full, R. J., Dudley, R., Koehl, M.A. R., Libby, T. \& Schwab, C. (2015). Interdisciplinary laboratory course facilitating knowledge integration, mutualistic teaming, and original discovery. Integrative and Comparative Biology, 55(5), 912-25.

Furutani, S. S. (2007). "How does one successfully implement learning centers the third grade level?". Master's Thesis, Pacific Lutheran University, Washington.

Gerçek, C. (2010). Students views on learning stations about smooking. Procedia Social and Behavioral Sciences, 2, 4581-4586.

Gökyer, N. (2012). Ortaöğretim okullarındaki devamsızlık nedenlerine ilişkin öğrenci görüşleri. Kastamonu Eğitim Dergisi, 20(3), 913-938.

Howatson, G. B. (1971). An attempt to evaluate a work centers approach to teaching at the second grade level. National Association for Gifted Children, 1(1), 18-23.

Jones, D. J. (2007). The Station Approach: How to Teach With Limited Resources http://www.nsta.org/publications/news/story.aspx?id=53323 adresinden Mayıs 2017 tarihinde ulaşılmıştır.

Kaplan, S. (1999). A learning center approach to independent study "teaching for high potential". National Association for Gifted Children, 1(1), 18-23.

Kayhan, M. \& Koca, S. (2004). Matematik eğitiminde araştırma konuları. Hacettepe Üniversitesi Eğitim Fakültesi Dergisi, 26, 72-81. 
Kılıç, A. \& Sağlam, N. (2004). Biyoloji eğitiminde kavram haritalarının öğrenme başarısına ve kalıcılığına etkisi. Hacettepe Üniversitesi Eğitim Fakültesi Dergisi, 27, 155-164.

Kırkkılıç, A. \& Akyol, H. (2007). İlköğretimde Türkçe öğretimi. Ankara: Pegem Akademi.

Kocamanoğlu, D. Ö. (2014). Öğrenme merkezleri kullanılarak oluşturulan bir okul öncesi eğitim sınıfında çocukların sanat ürünlerinin incelenmesi ve estetik yargılarının belirlenmesi. Yüksek Lisans Tezi, Ankara Üniversitesi Eğitim Bilimleri Enstitüsü, Ankara.

Lebak, K. (2005). "Connecting outdoor field experiences the classroom learning: a qualitative study of the participation of students and teachers in learning science". Doctoral Dissertation, Pennsylvania University, Pennsylvania.

Lindemann-Matthies, P., Constantinou, C., Lehnert, H.-J., Nagel, U., Raper, G. \& Kadji-Beltran, C. (2011). Confidence and percieved competence of preservice teachers to implement biodiversity education in primary schools-four comparative case studies from Europe. International Journal of Science Education, 33(16), 2247-2273.

Maden, E. \& Durukan, S. (2010). İstasyon tekniğinin yaratıcı yazma becerisi kazandırmaya ve derse karşı etkisi. Türk Bilimi Araştırmaları, 28(28), 299-312.

Manuel, B. (Eds.) (1974). How to build a learning station: everything a teacher should know. Massachusets: Merimack.

MEB. (2016). Talim Terbiye Başkanlığı ortaöğretim biyoloji dersi öğretim programı mebk12.meb.gov.tr/meb/iys/dosyalar sayfasından 23 Mayıs 2017 tarihinde erişilmiştir.

Mergen, H. H. (2011). İlköğretim 5. sınıf sosyal bilgiler dersinde öğrenme istasyonları uygulamasının akademik başarıya ve kalıcılığa etkisi. Yüksek Lisans Tezi, Afyon Kocatepe Üniversitesi,Sosyal Bilimler Enstitüsü, Afyon.

Murphy, J. \& Decker, K. (1989). Teachers' use homework in high schools. Journal of Educational Research, 82(5), 261-269.

Ocak, G. (2010). The effect of learning stations on the level of academic success and retention of elementary school students. The New Education Review, 21(2), 146-156.

Porter, E. J. (2014). "Classroom learning centers: study of a junior high school learning assisted program in mathematics". Master's Thesis, Pacific Lutheran University, Washington.

Ratnayaka, H. H. (2017). An on-campus botanical tour to promote student satisfactio and learning in a university level biodiversity or general biology course. Education Sciences, 7, 18-29.

Robert, P. H. (1999). "Effects of multisensory resources on the achievement and science attitudes of seventh grade suburban students taught science concepts on and above grade level". Doctoral Dissertation, St. John's University, New York.

Saygın, Ö., Atılboz, N. G. \& Salman, S. (2006). Yapılandırmacı öğretim yaklaşımının biyoloji dersi konularını öğrenme başarısı üzerine etkisi: canlılığın temel birimi hücre. Gazi Eğitim Fakültesi Dergisi, 26(1), 51-65. 
Schurr, S. L. (1995). Prescription for success in the heterogeneous classroom. Virginia: National Middle School Assosiation.

Sönmez, V. (2007). Öğretim ilke ve yöntemleri. Ankara: Anı.

Strauber, S. K. (1982). Language learning stations. Foreign Language Annals, 14(1), 31-36.

Sunday, B. A. (1979). An investigation of learning stations for elementary art. Washington: ERIC.

Tanner, K. D. (2013). Structure matters: Twenty-one teaching strategies to promote student engagement and cultivate classroom equity. CBE-Life Sciences Education, 12, 322-331.

Tay, B. (2008). Özel öğretim yöntemleriyle sosyal bilgiler öğretimi. Ankara: Pegem Akademi.

Vacca, J. L. \& Vacca, R. T. (1976). Learning stations: how to in the middle grades. Journal of Reading, 19(7), 563-567.

Weathersby, R. \& Freyberg, R. (2008). Study guide and SPSS manual. (Statistics for the Behavioral Sciences. Nolan, S. A. and Heinzen, T. E.). New York: Worth

Young, A. G. \& Pearce, S. (2013). A beginner's guide to factor analysis: focusing on exploratory factor analysis. Tutorials in Quantitative Methods for Psychology, 9(2), 79-94.

Zentall, S. S. \& Zantall, T. R. (1976). Activity and task performance of hyperactive children as a function of environmental simulation. Journal of Consulting and Clinical Psychology, 44(5), 693. 